\title{
Smart Techniques' Implementation for Small Entities and Central Power Grid in Almaty, Kazakhstan: Challenges and Possibilities
}

\author{
G. B. Nurpeissova, D. V. Panyukova, and A. T. Nurpeissov
}

\begin{abstract}
With growth of renewable energy sources' use the uncertainty in power grids is increasing tremendously. Optimal control and the equipment dispatching become challenging task for both central supplier and power consumer. Implementation of smart approach gives opportunity to provide such control with less human resources and power losses. In the article recently used techniques for control and dispatching in central grid of Almaty is described. Beside that new smart control methods and their possibilities within power system of Kazakhstan are reviewed. As a result, best solutions for the power system's control in both small entities and central grid are proposed.
\end{abstract}

Index Terms - Dispatching, optimal control, power grid, power system, renewable energy sources, smart grid.

\section{INTRODUCTION}

$\mathrm{C}$ IONTROL AND DISPATCHING of central power supply were always associated with variety of power demand. Its random nature was overcome by advanced forecasting of main grid parameters and by strict policy for industrial costumers' planned demand. But nowadays this approach is becoming less and less effective; because of wide spread usage of renewable energy sources (RES).

According to [1] RES' use worldwide has grown up to 20 $555 \mathrm{TWh}$ at 2012. And will not stop and reach incredible 55 $000-85000 \mathrm{TWh}$ in 2050. In Kazakhstan trends are not as good yet. So, according to the forecast balances of the Ministry of Energy of the Republic of Kazakhstan [2] in next 6 years the internal power demand in the republic will increase by 2.4 billion kWh annually. Concurrently power output of existing stations will be orderly lowered for 1.5 billion $\mathrm{kWh}$ annually till 2023. It is planned to accomplish by both commissioning new stations and active use of renewable

G. B. NURPEISSOVA, is with Engineering School, Eurasian Technological University, Almaty, Kazakhstan.

D. V. PANYUKOVA, is with Department of Automation and Control, The Kazakh National Research Technical University after K.I.Satpaev, Almaty, Kazakhstan, (e-mail: haleth@ mail.ru).

A. T. NURPEISSOV, is with Engineering School, Eurasian Technological University, Almaty, Kazakhstan.

Manuscript received May 14, 2018; accepted October 20, 2018. DOI: $10.17694 /$ bajece. 475538 energy sources. Thus renewable energy sources use will grow by 0.5 billion $\mathrm{kWh}$ annually till 2020 and 1 billion $\mathrm{kWh}$ annually till 2023.

RES are working directly on natural power gained from water, wind, sun, temperature. Most of those sources are partly predictable. Hence RES' use brings even more uncertainty in power grid either central or private. And power grid's dispatching and control become even more complex task.

Main goal for dispatching and control is to provide correct amount of power for customers with decreasing of power losses and power cost. It can be achieved both by reducing distance between supplier and customer and by minifying number of power plants and other equipment.

The techniques recently used in Kazakhstan's power grids are described in "Actual central grid" chapter of the article.

"New approaches" chapter is devoted to several approaches that are offered by international scientists and engineers.

At "Implementation perspectives" chapter possibilities and challenges of previously described methods in Kazakhstan are discussed.

In "Conclusion" general review of future perspectives of power grid control in the republic is provided.

\section{ACTUAL CENTRAL GRID}

In Kazakhstan power grid's work regulates by market system and norms of governmental standard 32144-2013 "Electric energy. Electromagnetic compatibility of technical equipment. Power quality limits in the public power supply systems" [3]. It fully matches European standard EN 50160:2010 "Voltage characteristics of electricity supplied by public distribution networks" [4].

The standard [3] reveals values and norms of electric power quality at delivery point of $50 \mathrm{~Hz}$ of alternating current (AC) from general purpose power grid to customer of low, middle and high voltage. It includes frequency, values and forms of voltage and symmetry of voltages in three-phase systems. Also [3] regulates accidental changes in forms of voltage that leads to voltage deviation from rated. Such accidents occur from hardware damages of the grid or external effects (from nature or human factor). They include voltage interruption, voltage fall, voltage swell and impulse voltages.

Nonregulated decisions are made according to trade factors. Structure of wholesale market of electric power in the republic includes: 
- Decentralized sale and purchase power market (bilateral purchase/sale agreements);

- Centralized power market, where purchase and sale of power for short-term (spot-trading), middle-term (week, month) and long-term (quarter, year) is provided;

- Real time balancing market, working for physical and financial regulation of hourly misbalances, appeared daily between real and agreed supply-consumption of electric power which is described in [5];

- System and supplementary service market;

- Electrical capacity market.

System operator of Kazakhstan's central power grid is KEGOC JSC by order 61 of Ministry of Energy of Republic of Kazakhstan by 17.10.2014. And its' functions are:

- to provide system service for transmission of electrical energy by national power grid according to an agreement, ensure its' technical maintenance;

- to provide system service for technical dispatching and centralized real time control of power grid's operating regimes according to agreements, including planning of power balances and daily graphic of supply-demand of electric power;

- to ensure operational reliability of power grid in the republic;

- to provide system service for regulation of electrical capacity;

- to provide system service for balancing supply-demand of electric power;

- to perform financial regulation of electric power misbalances strictly according to laws and regulations of Republic of Kazakhstan;

- to determine amount, structure and distribution of power reserves between power supplying entities and also involvement of power reserves in central grid's work;

- to provide real time functionality of the balancing market of electric power as well as the system and supplementary service market;

- to cooperate with power grids of neighboring countries to control and stabilization of parallel work regimes and electric power regulation;

- to provide technical and methodological guidance to create united information system, automation system of commercial accounting of electric power, associated hardware of relay protection and emergency controls for all entities of electric power's wholesale market;

- to ensure equal terms for access to the central power grid;

- to provide all necessary information excluding commercial or other legally protected secret for all entities of electric power's wholesale market;

- to coordinate a release for maintenance of main equipment of power plants, transformer plant, electrical energy transmission line, relay protection and emergency controls, technological control systems and to ensure their availability for service;

- to participate in operational regimes' design for hydraulic power plants due to their hydro economic balances and central grid regimes;

- to provide computation of forecasting balances of electric power;

- to provide functioning of electric capacity market;
- to provide certification of power capacity of supplying plants;

- to present quarterly information about coordinated schemes of power capacity supply.

Nowadays 118 both commercial and governmental electric power plants are utilized in the republic as stated in [6]. Biggest of them are:

- Ekibastuz GRES-1 LLP named after B.G. Nurzhanov;

- Ekibastuz GRES-2 Power Plant JSC;

- Power plant of EEC JSC, ERG, Eurasian Group;

- GRES of Kazakhmys Energy LLP;

- Zhambyl GRES JSC named after T.I. Baturov;

- Bukhtarma Hydro Power Complex of Kazzinc LLP;

- AES Ust-Kamenogorsk HPP LLP;

- AES Shulbinsk HPP LLP.

For 01.01.2017 their total installed capacity was 22055.5 MW. Whereas available capacity was 18789.1 MW. Mostly the plants can be divided in three groups:

- Large thermal plants of national importance, which work is defined in [7];

- Large hydraulic power plants of national importance;

- Combined heat power plants of industrial importance.

As can be seen most of the plants are either using conventional type of energy or using more predictable RES type as energy of falling water or fast running water. So, central power market in the country is not yet affected by uncertainty of RES.

If consider private sector, use of small RES plants can impact only on local power systems not influencing central power grid as is researched in [8]. Because unlike European system there are no possibility for supply of power leftover back to central grid. But it is promised to legally provide such opportunity in the nearest future [9].

For now, to provide power supply entity has to:

- have licenses as required by the laws of Kazakhstan;

- have access to the national or regional electric network;

- supply at least $1 \mathrm{MW}$ of electricity on daily base to the wholesale market and have commercial metering systems, telecommunications harmonized with the System Operator.

Due to large territory and small population of the country not all of the inhabited areas have access to central power grid as mentioned in [10]. That is the main market for RES' use as it is more efficient in a long run than diesel generators as proved in [11]. The reason why diesel generators are more employed for now is that it requires less capital investments.

For any power grid the control process can be reduced to minimization of power cost $\mathrm{M}$ with at least one constraint:

$$
E-T=C
$$

Here: $E$ - total power generated by all plant of the grid, $\mathrm{kWh}$;

$T$ - total power loses for transportation of electric energy from a supplier to a customer, $\mathrm{kWh}$;

$C$ - total power demand from the customers, $\mathrm{kWh}$.

With a growth of demand $C$ more $E$ is needed to cover it and at the same time more distant power plants are connected, which leads to $T$ increase and more $E$ is required.

In conventional power grids the main source of uncertainty was $C$. But with RES' plants appearance $E$ is also becoming 
stochastic value. Whereas Eq.1 describes even more complex interrelationship.

\section{NEW APPROACHES}

Electric power control and dispatching with RES' influence is not a newly appeared task for worldwide engineers' community. Consequently, there several approach offered by scientific community within last ten years. Some of them are mentioned in this chapter.

\section{A. Dynamic tariffs}

First and logical approach is to regulate one of the probability factors - power consumption. The only possible way is to stimulate customers to use less energy at the peak times when it is harder to cover power demand by dynamic tariffs. If take mathematical model from Eq. (1) such methodology helps to change distribution of $\mathrm{C}$ throughout a day and make it more linear.

Dynamic tariffs are far implemented in developed countries [12]. Such power tariffs are thoroughly legally regulated and have many application variants for private power systems like in $[13,14]$.

But such control technique is effective only for system at a state level, while for small communities or autonomous power grids it's not applicable.

\section{B. Energy storage}

Other possibility is to use some kind of power buffer for uncertain supplying plant and unpredictable consumer. Such buffer can be provided by some kind of energy storage.

This energy storage or, in other words, accumulator will need essential amount of material and human resources for proper implementation and operation. There several methodologies to calculate the capacity needed as, for example, in [15-17].

In situation with autonomous power grid of any size as in $[18,19]$ it's almost only opportunity to have energy reserve and not to lose power leftover at some point.

This method mathematically can be represented in Eq. (1) as a new variable $B$ and will transform to:

$$
\begin{cases}\Delta B=E-T-C, & \text { if } \mathrm{E}>\mathrm{C}+\mathrm{T}, \\ C=E-T+\Delta B, & \text { if } \mathrm{E}<\mathrm{C}+\mathrm{T} .\end{cases}
$$

Here: $\Delta B$ - difference of energy stored in any kind of accumulator, $\mathrm{kWh}$.

\section{Electric powered vehicle or EPV}

In parallel with growth of RES' use electric powered vehicles are becoming more and more spreading. They start to be main part of power consumption in private sector. At the same time, they don't have much difference from specific energy storage for a power grid as mentioned in [20]. Hence they also can be used as previously mentioned buffer. The only concern is to provide optimum schedule of EPV's use beyond the power system.

\section{Decentralization}

Previously described approaches are mostly focused on minifying number of power plants and other equipment by reducing peak demand. But other distance between supplier and customer was out of focus.

For decentralization it's vice versa. This solution can not affect consumers. It concentrates on finding for each customer nearest supplier as described in [21]. By that energy expenses to match norms from [3] decreases significantly.

With wide implementation of RES plants private power system will become complex agent for a power grid. Because it will switch the role from consumers to suppliers and backwards according to own plants' output and own demand. Therefore, power grid can be considered as a multi-agent system where interconnection between agents can be described with Holonic architecture as in [22].

The main principle of Holonic architecture is that every big system or super-holon can be divided into subsystems or holons that can regulate most of inner processes without interaction with other part of super-holon. Whereas the holon become the super-holon for its own subsystems. Such architecture can penetrate power grid till exact EPVs, power plants or end consumer.

For example, if power demand can be covered by won power plants of the holon it will use own computational capabilities to control and dispatching. But if inner power resources will not be enough it will interact with his superholon as a consumer. Visa versa if there is leftover energy within the holon it become a supplier in higher level.

Such approach permits to minimize distance between consumer and supplier as well as decreasing the demand for computational and technical capabilities of central grid. Also it accelerates a response from an end consumer or supplier.

Whereas dispatching and control process is the same classical optimization task as can be seen in [23] to minimize power cost $\mathrm{M}$ with at least one constraint:

$$
E_{h}-T_{h}=C_{h}
$$

Here: $E_{h}$ - total power generated by all plant of one holon, $\mathrm{kWh}$;

$T_{h}$ - total power loses for transportation of electric energy from a supplier to a customer of a holon, $\mathrm{kWh}$;

$$
C_{h} \text { - total power demand from one holon's customers, }
$$
kWh.

The difference is that when it is not enough power sources within one holon it requests for supply from super-holon (power grid of higher level).

\section{IMPLEMENTATION PERSPECTIVES}

\section{A. Dynamic tariffs}

Energy system of Kazakhstan is still fuel oriented. This is due to high accessibility and relatively low cost of natural gas and coal. Whereas RES are very presented in the republic with current low cost of energy from conventional sources this trend is hardly changeable as discussed in [24]. Implementation of large and middle RES' plants is a risky investment at such high-risk business environment and 
unformed urge as researched in [25]. That factors have an impact on country-wide absents of dynamic tariffs for electric power. And for foreseen future it is not an appropriate approach for the power grid.

\section{B. Energy storage}

RES use in Kazakhstan is directly connected with energy storage technology as described in [26]. As mentioned previously there is no other possibility to deal with power leftovers. That power cannot be given back to central grid either because of regulations absents or absents of central grid itself.

To explain last statement, it's necessary to mention that most of the rural territory hasn't got any connection with central grid and work on totally autonomous power supply. Whereupon cannot work without some kind of energy storage.

\section{C. $E P V$}

Big EPVs are not very presented in the republic both in urban and rural areas. But number of them is growing year by year. Anyhow EPV as an energy storage device can be used only with high involvement of end consumers in power grid operation. Otherwise it's hardly possible to provide scheduled charge of EPV as it is mandatory for such methodology.

\section{Decentralization}

For any regulation changes there should be either economic or social interest for government. As described previously and also researched in [27] there is no economic reason for changing system for fuel oriented energy sector of the country. At the same time globally the power grid is already decentralized if taking autonomous rural territories into account. And Holonic architecture can provide massive economic impact for private power grids at isolated territories. And minimize expanses for energy storage equipment.

\section{CONCLUSION}

Nowadays Kazakhstan energy sector is mostly fuel based with some amount of hydro energy use. But according to [28] most economic effect can be achieved by use of solar energy that is more than enough represented in geographical location of the country. Whereas hydro energy can be utilized even more and provide social effect. Also wind and biomass can impact on ecological situation of the republic.

And while the energy market doesn't have almost any practical motivation to force RES implementation in the immediate future the end users are concerned about possibility to use small plants in their daily live. Especially in rural territories distant from central grid as mentioned in [11].

Hence it appears that dynamic tariffs are not very applicable in case of Kazakhstan's central grid. But use of energy storage and in some future EPVs is indispensable. Furthermore, RES expansion is in straight connection with energy storage technologies. Formalization of decentralized autonomous part of republican energy sector is also forthcoming for rural and distant group of entities by its development in a nearest future.

\section{REFERENCES}

[1] Wina Crijns-Graus, "Renewable Energy: Past Trends and Future Growth in 2 Degrees Scenarios", Energy Procedia, No.100, 2016, pp. 14-21.

[2] Order №460 from 26th of October 2016 of Ministry of Energy of Republic of Kazakhstan "About confirmation of forecasting balances of electric power for 2017-2023 years".

[3] National State Standard 32144-2013 "Electric energy. Electromagnetic compatibility of technical equipment. Power quality limits in the public power supply systems".

[4] European Standard EN 50160:2010 "Voltage characteristics of electricity supplied by public distribution networks".

[5] Makpal Assembayeva, Jonas Egerer, Roman Mendelevitch, Nurkhat Zhakiyev, "A spatial electricity market model for the power system: The Kazakhstan case study”, Energy, No. 149, 2018, pp. 762-778.

[6] Kazakhstan Electric Power Industry Key Factors| KEGOC, http://www.kegoc.kz/ru/elektroenergetika/elektroenergetika-kazahstanaklyuchevye-fakty.

[7] Nurkhat Zhakiyev, Yerbol Akhmetbekov, Javier Silvente, Georgios M. Kopanos, "Optimal energy dispatch and maintenance of an industrial coal-fired combined heat and power plant in Kazakhstan", Energy Procedia, No. 142, 2017, pp. 2485-2490.

[8] M. Yilmaz, F. Kentli "Increasing of electrical energy with solar tracking system at the region which has Turkey's most solar energy potential". Journal of Clean Energy Technologies,3(4), 287-290.

[9] K. Kulikova, "How much can Kazkahstan citizens gain from electric power", Karavan, 19.01.2016, https://www.caravan.kz/gazeta/kakiesummy-kazakhstancy-zarabotayut-na-ehlektroehnergii-87862/

[10] G. B. Nurpeissova, T.B. Nurpeissova, D. V. Panyukova, "Estimation of wind energy resources at Kazakhstan territory for autonomous power supply of low power consumers", 14th International Multidisciplinary Scientific GeoConference SGEM 2014, SGEM 2014 Conference Proceedings, Albena, Bulgary, Book 4, Vol. 1, 2014, pp. 213-220.

[11] G. B. Nurpeissova, D. V. Panyukova, "Autonomous power supply systems based on wind power plants for agroformations", 14th International Multidisciplinary Scientific GeoConference SGEM 2014, SGEM 2014 Conference Proceedings, Albena, Bulgary, Book 4, Vol. 1, 2014, pp. 49-56.

[12] F. Kentli and M. Yilmaz. "Improving Tracking Efficiency of Two-Axis Sun Tracking Systems." Energy Harvesting and Energy Efficiency. Springer, Cham, 2017. 179-203.

[13] Henrique Pombeiro, Maria João Machado, Carlos Silva, "Dynamic programming and genetic algorithms to control an HVAC system: Maximizing thermal comfort and minimizing cost with PV production and storage", Sustainable Cities and Society, No. 34, 2017, pp. 228-238.

[14] Vivek Tomar, G. N. Tiwari, "Techno-economic evaluation of grid connected PV system for households with feed in tariff and time of day tariff regulation in New Delhi - A sustainable approach", Renewable and Sustainable Energy Reviews, No. 70, 2017, pp. 822-835.

[15] Kenneth K. Zame, Christopher A. Brehm, Alex T. Nitica, Christopher L. Richard, Gordon D. Schweitzer III, "Smart grid and energy storage: Policy recommendations", Renewable and Sustainable Energy Reviews, No. 82/1, 2018, pp. 1646-1654.

[16] Andrea Michiorri, Jesus Lugaro, Nils Siebert, Robin Girard, George Kariniotakis, "Storage sizing for grid connected hybrid wind and storage power plants taking into account forecast errors autocorrelation", Renewable Energy, No. 117, 2018, pp. 380-392.

[17] Yang Zhang, Pietro Elia Campana, Anders Lundblad, Jinyue Yan, "Comparative study of hydrogen storage and battery storage in grid connected photovoltaic system: Storage sizing and rule-based operation", Applied Energy, No. 201, 2017, pp. 397-411.

[18] K.A. Kavadias, D. Apostolou, J.K. Kaldellis, "Modelling and optimisation of a hydrogen-based energy storage system in an autonomous electrical network", Applied Energy, No. 227, 2018, pp. 574-586.

[19] G. Puglia, M. Moroni, R. Fagnani, G. Comodi, "A design approach of off-grid hybrid electric microgrids in isolated villages: a case study in Uganda”, Energy Procedia, No. 105, 2017, pp. 3089-3094.

[20] Kristyna Friedrischkova, David Vala, "Energy-independent concept of a house using an electric vehicle traction", IFAC-PapersOnLine, No. 49/25, 2016, pp. 535-540.

[21] Sebastian Weckmann, Timm Kuhlmann, Alexander Sauer, "Decentral energy control in a flexible production to balance energy supply and demand", Procedia CIRP, No. 61, 2017, pp. 428-433. 
[22] Adriano Ferreira, Ângela Ferreira, Olivier Cardin, Paulo Leitão, "Extension of holonic paradigm to smart grids", IFAC-PapersOnLine, No. 48/3, 2015, pp. 1099-1104.

[23] Javad Ansari, Amin Gholami, Ahad Kazemi, "Multi-agent systems for reactive power control in smart grids", International Journal of Electrical Power \& Energy Systems, No. 83, 2016, pp. 411-425.

[24] Marat Karatayev, Stephen Hall, Yelena Kalyuzhnova, Michèle L.Clarke, "Renewable energy technology uptake in Kazakhstan: Policy drivers and barriers in a transitional economy", Renewable and Sustainable Energy Reviews, No. 66, 2016, pp. 120-136.

[25] James MacGregor, "Determining an optimal strategy for energy investment in Kazakhstan", Energy Policy, No. 107, 2017 pp. 210-224.

[26] M. Assembayeva, N. Zhakiyev, Y. Akhmetbekov, "Impact of storage technologies on renewable energy integration in Kazakhstan", Materials Today: Proceedings, No. 4/3/A, 2017, pp. 4512-4523.

[27] Marat Karatayev, Michèle L. Clarke, "A review of current energy systems and green energy potential in Kazakhstan", Renewable and Sustainable Energy Reviews, No. 55, 2016, pp. 491-504.

[28] Salman Ahmad, Abid Nadeem, Gulzhanat Akhanova, Tom Houghton, Firdaus Muhammad-Sukki, "Multi-criteria evaluation of renewable and nuclear resources for electricity generation in Kazakhstan" Energy, No. 141, 2017, pp. 1880-1891.

\section{BIOGRAPHIES}

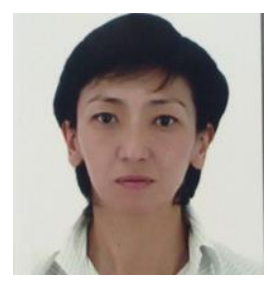

GULNARA B. NURPEISSOVA Matay, Kazakhstan, in 1965. She received the specialist degree in automation and telemechanic engineering from the Leningrad Electrotechnical Institute after V.I. Ulyanov (Lenin), Saint-Petersburg, Russia, in 1988, the Ph.D. and the Doctor Habil. of Tech. Sci. degree in "Technologies and mechanization instruments for agriculture" specialty from KazSRIMEA, Almaty, Kazakhstan, in 2005 and in

2010 accordingly.

From 2012 to 2016, she was a Vice-President with the Kazakh Automobile and Road Academy named after L.B. Goncharov, Almaty, Kazakhstan. From 2016 to 2018, she was a Vice-President for Academic Affairs with the Eurasian Technological University, Almaty, Kazakhstan. Since 2016, she has been a Professor with Engineering School, Eurasian Technological University. She is the author of one book, more than 70 articles, and 4 patents. Her research interests include renewable energy, information technologies in general, in transport and in agrarian sector, smart grids.

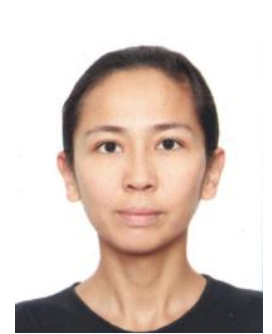

DINA V. PANYUKOVA Saint-Petersburg, Russia, in 1987. She received the B.S. degrees in automation and control engineering from the Kazakh National Technical University after K.I.Satpaev, Almaty, Kazakhstan in 2009 and the M.S. degree in automation and control engineering from Saint Petersburg Electrotechnical University "LETI", Saint-Petersburg, Russia, in 2011. Started the Ph.D. degree program in automation and control engineering in the Kazakh National Research Technical University after K.I.Satpaev, in 2016.

From 2009 to 2016, she was firstly Lecturer and then Senior Lecturer with Kazakh Automobile and Road Academy named after L.B. Goncharov. From 2016 to 2017 she was a Lecturer with the Kazakh National Technical University after K.I.Satpaev. She is the author of more than 10 articles. Her research interests include intellectual systems, load forecasting, renewable energy, smart grids, information technologies.

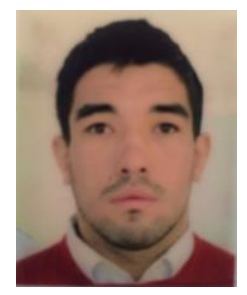

ADILKHAN T. NURPEISSOV Almaty, Kazakhstan, in 1992. He received the B.S. degrees in electric power engineering from the Almaty University of Power Engineering and Telecommunication, Kazakhstan in 2015. Started the master's degree program in electric power engineering in Eurasian Technological University, Almaty, Kazakhstan in 2017.

Since 2015, he has been an Instrumentation and Control Systems Engineer with JSC ALES CHPP 1, Almaty, Kazakhstan. His research interests include renewable energy, electronics and other electrical equipment, mechanical engineering, traditional energy, relay protection and automation. 